\title{
KEDUDUKAN DAN FUNGSI DPD DALAM SISTEM \\ PARLEMEN BIKAMERAL INDONESIA
}

\author{
Bukhari Yasin ${ }^{1}$ \\ ${ }^{1}$ Fakultas Hukum Universitas Bojonegoro \\ Email : masteroflaw16@gmail.com ${ }^{1}$
}

\begin{abstract}
ABSTRAK
Penelitian ini bertujuan untuk mengetahui peran dan fungsi DPD dalam sistem parlemen dua kamar Indonesia. Penelitian ini merupakan jenis penelitian normatif, dengan menggunakan pendekatan peraturan perundang-undangan, pendekatan konseptual, dan pendekatan historis. Pengumpulan bahan hukum yaitu dengan menggunakan pendekatan kepustakaan, kemudian dianalisis secara sistematis. Hasil penelitian menunjukan bahwa peran dan fungsi DPD dalam sistem parlemen dua kamar Indonesia adalah secara konstitusional hanya terbatas pada fungsi legislasi, fungsi anggaran, maupun fungsi kontrol yang berkaitan dengan materi atau substansi mengenai otonomi daerah, hubungan pusat dan daerah, pembentukan dan pemekaran serta penggabungan daerah, pengelolaan sumber daya alam dan sumber daya ekonomi lainnya serta yang berkaitan dengan perimbangan keuangan pusat dan daerah.
\end{abstract}

Kata Kunci : Kedudukan, Fungsi, DPD, Parlemen, Bikameral

\section{PENDAHULUAN}

Indonesia merupakan salah satu negara yang menganut sistem pemerintahan presidensil. Dimana kekuasaan Presiden, selain sebagai kepala negara juga sebagai kepala pemerintahan. Dengan demikian, secara otomatis ia juga membahawi kabinet atau para menteri dan harus bertanggungjawab atas pelaksanaan urusan pemerintahan yang dijalankannnya. ${ }^{1}$ Oleh karena itu untuk mengontrol fungsi kekuasaan ini dibentuklah suatu badan perwakilan atau yang sering disebut

${ }^{1}$ Lihat dalam ketentuan Pasal 17 UndangUndang Dasar Negara Republik Indonesia Tahun 1945. dengan istilah parlemen atau lembaga legislatif.

Di Indonesia sendiri istilah badan perwakilan ini kemudian diberi nama Majelis Permusyawaratan Rakyat yang terdiri dari 2 (dua) unsur yaitu Dewan Perwakilan Rakyat (DPR) dan Dewan Perwakilan Daerah (DPD). Di dalam Pasal 2 ayat (1) Undang-Undang Dasar Negara Republik Indonesia Tahun 1945, menentukan bahwa Majelis Permusyawaratan Rakyat terdiri atas anggota Dewan Perwakilan Rakyat dan anggota Dewan Perwakilan Daerah yang dipilih melalui pemilihan umum dan diatur lebih lanjut dengan undang-undang. Dari sini lah kemudian muncul istilah 
parlemen dua kamar (bikameral) dalam konteks negara Republik Indonesia.

Menurut Jimly Asshiddiqie, ketika pertama kali didirikan pada tahun 1945, struktur parlemen negara kita diidealkan berkamar tunggal (unikameral) tetapi dengan variasi yang dikaitkan dengan teori kedaulatan rakyat yang dibayangkan dapat diorganisasikan secara total ke dalam suatu organ bernama Majelis Permusyawaratan Rakyat. ${ }^{2}$ Sistem parlemen dua kamar atau bikameral dalam konteks Indonesia dimulai ketika dibentuknya Dewan Perwakilan Daerah (DPD) pada tahun 2004. Sistem dua kamar (bikameral) menggambarkan praktik pemerintahan yang menggunakan dua kamar legislatif atau parlemen.

Pembentukan DPD semula dimaksudkan dalam rangka mereformasi struktur parlemen menjadi dua kamar (bikameral). Dimana dengan adanya dua kamar DPR dengan DPD tersebut diharapkan penyelenggaraan fungsi legislasi dapat berjalan secara memadai serta bisa menampung aspirasi yang lebih luas. DPR merupakan cermin representasi secara politik, sedangkan DPD merupakan cerminan representasi secara teritorial atau kewilayahan. Tetapi kemudian yang terjadi dan berkembang sampai saat ini peran dan fungsi yang dimiliki oleh DPD tidak begitu saja berjalan tanpa adanya hak dan kewenangan yang tepat untuk mengoptimalkan fungsinya.

Superioritas atau monopoli fungsi legislasi DPR seperti itu ternyata

2 Jimly Asshiddiqie, Hukum Tata Negara dan Pilar-Pilar Demokrasi, Sinar Grafika, Jakarta, 2011, hal. 13. telah menjadi catatan banyak pakar untuk perlunya

koreksi terhadap Pasal 20 hasil amandemen tersebut. Karena dalam lembaga perwakilan rakyat yang menganut sistem bikameral, dua lembaga yang ada memiliki harmoni kewenangan dalam fungsi legislasi. Dalam hal ini, meskipun Majelis Tinggi (Senates/House of Lords) tidak memiliki hak untuk mengajukan rancangan undangundang tetapi berhak untuk mengubah, mempertimbangkan, atau menolak (veto) rancangan undangundang dari Majelis Rendah (Kongress/House of Representatives). Di beberapa negara, jika kewenangan seperti itu tidak ada, maka House of Lords diberi hak untuk dapat menunda pengesahan rancangan undangundang yang telah mendapat persetujuan dari House of Representatives.

Hal yang demikian itu tentu dimaksudkan agar fungsi legislasi DPR tidak dijadikan kekuatan politik untuk melanggengkan kepentingan partai-partai politik yang mendominasi DPR. Sebab, menurut banyak pakar, dengan fungsi legislasi DPR yang ada sekarang ini sering digunakan sebagai instrumen untuk memproduksi undang-undang yang memperkuat supremasi DPR dengan tanpa dialasi kebutuhan rasional. Pendapat seperti itu tentu debatable, sebab meskipun DPD tidak memiliki fungsi legislasi secara utuh tatapi tidak serta merta politik hukum perundang-undangan kita telah menyimpang dari konstitusi. Karena jika hal yang demikian itu terjadi maka pihak yang berkepentingan yang memiliki legal standing dapat mengajukan keberatan terhadap isi 
undang-undang ke Mahkamah Konstitusi.

Selain itu, evaluasi dan pertanggungjawaban juga sangat diperlukan dalam rangka akuntabilitas secara publik bukan hanya laporan semata. Selama ini, hak yang dimiliki oleh DPD hanya sebatas pertimbangan tanpa mempunyai kewenangan untuk memutuskan. Padahal kepentingan daerah adalah hal yang sangat penting disamping kepentingan nasional, karena negara tidak akan maju tanpa dukungan dari daerah. Jadi dengan belum adanya hak dan kewenangan yang lebih untuk DPD menimbulkan pelaksanaan peran dan fungsi yang tidak optimal. DPD cenderung hanya menyerap aspirasi tanpa bisa memberikan solusi terutama yang berkaitan dengan legislasi.

Berdasarkan hal tersebut di atas mendorong peneliti untuk mengangkat tema ini yakni tentang Kedudukan dan Fungsi DPD Dalam Sistem Parlemen Bikameral Indonesia.

Berdasarkan uraian tersebut di atas, maka permasalahan yang diajukan dalam penelitian ini adalah terkait peran dan fungsi DPD dalam sistem parlemen dua kamar Indonesia.

\section{METODE PENELITIAN}

\section{Jenis Penelitian}

Dalam penelitian ini menggunakan jenis penelitian hukum normatif yaitu dengan bertumpu pada suatu peraturan peraturan perundangundang maupun konsep-konsep hukum yang dikemukakan oleh para ahli.

\section{Metode Pendekatan}

Di dalam penelitian ini menggunakan metode pendekatan peraturan perundang-undangan (statute approach) dan pendekatan konsep (conseptual approach). ${ }^{3}$

a. Pendekatan perundang-undangan (statute approach) adalah pendekatan yang dilakukan dengan menelaah semua undangundang dan regulasi yang bersangkut paut dengan isu hukum yang sedang ditangani. Pendekatan perundang-undangan dalam penelitian hukum normatif memiliki kegunaan baik secara praktis maupun akademis. ${ }^{4}$

b. Pendekatan konsep (conseptual approach) adalah pendekatan yang beranjak dari pandanganpandangan dan doktrin-doktrin yang berkembang di dalam ilmu hukum, guna menemukan ide-ide yang melahirkan pengertian, konsep, dan asas hukum yang relevan, sebagai sandaran dalam membangun suatu argumentasi hukum dalam memecahkan isu hukum yang dihadapi. ${ }^{5}$

\section{Sumber dan Jenis Bahan Hukum}

Bahan hukum merupakan sarana dari suatu penelitian yang dipergunakan untuk memecahkan masalah yang ada. Bahan hukum tersebut terdiri dari bahan hukum primer dan bahan hukum sekunder. ${ }^{6}$

a. Bahan hukum primer Bahan hukum primer yaitu bahan hukum dasar atau bahan asli yang diperoleh dari tangan

3 Peter Mahmud Marzuki, Penelitian Hukum, Cet. 5, Edisi Pertama, PT Interpratama Offset, Jakarta, 2009, hal. 93.

${ }^{4}$ Ibid., hal. 96.

${ }^{5}$ Ibid., hal. 137.

6 Peter Mahmud Marzuki, Penelitian Hukum, Kencana Prenada Media Group, Jakarta, 2010, hal. 155. 
pertama atau dari sumber asalnya yang pertama dan belum diuraikan orang lain. Bahan hukum primer ini dari membaca peraturan dasar, peraturan perundang-undangan, dan norma hukum.

b. Bahan hukum sekunder

Bahan hukum sekunder adalah bahan-bahan hukum yang erat kaitannya dengan bahan hukum primer dan dapat membantu menganalisis dan memahami bahan hukum primer.

\section{Pengumpulan Bahan Hukum}

Proses pengumpulan bahan hukum yang dipergunakan dalam penyusunan penelitian ini antara lain dengan melakukan langkahlangkah dalam penelitian hukum, yaitu kajian pustaka, identifikasi badan hukum, editing, analisis dan mengeliminasi hal-hal yang tidak relevan untuk menetapkan isu hukum yang akan dipecahkan. pengumpulan bahan-bahan hukum yang sekiranya dipandang memiliki relevansi terhadap isu hukum, melakukan telaah atas isu hukum yang diajukan berdasarkan bahanbahan yang telah dikumpulkan, menarik kesimpulan dalam bentuk argumentasi yang menjawab isu hukum, memberikan preskripsi berdasarkan argumentasi yang telah dibangun dalam kesimpulan.

\section{Analisis Bahan Hukum}

Analisa bahan penelitian dalam penelitian ini menggunakan analisis normatif kualitatif, yaitu cara untuk memperoleh gambaran singkat suatu masalah yang tidak didasarkan atas angka-angka statistik melainkan didasarkan atas suatu peraturan perundangundangan yang berlaku maupun teori dan asas hukum serta berkaitan dengan permasalahan yang dibahas. Selanjutnya ditarik kesimpulan dengan menggunakan metode deduktif yaitu menyimpulkan pembahasan dari hal-hal yang bersifat umum menuju ke hal-hal yang bersifat khusus.

\section{PEMBAHASAN}

Lembaga perwakilan muncul sebagai konsekuensi lahirnya demokrasi langsung. Kata demokrasi berasal dari bahasa yunani kuno kata ini berasal dari lafal kata demos yang berarti rakyat dan kratein berarti memerintah dari kata kraten ini lalu menjadi kratos yang berarti pemerintahan. ${ }^{7}$ Selanjutnya secara harfiah, kata demokrasi berarti pemerintahan rakyat. Demokrasi sebagai suatu sistem pemerintahan diartikan sebagai pengertian demokrasi dalam arti sempit. Sedangkan, pengertian demokrasi dalam arti luas meliputi suatu sistem pemerintahan serta pengakuan adanya hak-hak asasi manusia ataupun persamaan akan hakikat manusia, bahkan lebih dari itu menyangkut berbagai sistem dalam masyarakat.

Hampir setiap negara mengklaim bahwa demokrasi telah menjadi roh atau prinsip dalam menyelenggarakan kehidupan berbangsa dan bernegara. Demokrasi telah menjadi istilah terhormat di seluruh penjuru dunia. ${ }^{8}$ Oleh karena itu istilah demokrasi bukanlah hal yang baru, melainkan sudah menjadi

\footnotetext{
7 Eggy Sudjana, Dasar dan Struktur Ketatanegaraan Indonesia (edisi revisi), Jakarta, Rinneka Cipta, 2008, hal.18.

8 Galang Asmara, Ombudsman Republik Indonesia Dalam Sistem Ketatanegaraan Republik Indonesia, Laksbang Yustitia, Surabaya, 2012, hal. 44.
} 
asas dalam kehidupan negara-negara di berbagai belahan dunia. Namun perlu dipahami bahwa konsep kekuasaan rakyat dalam hal ini adalah bisa dalam konteks kekuasaan secara langsung sebagaimana pernah diterapkan pada Yunani Kuno dan bisa pula dalam konteks kekuasaan secara tidak langsung yakni melalui perwakilan yang dipilih langsung oleh rakyat.

Menurut Galang Asmara bahwa ditinjau dari teori tentang bentukbentuk pemerintahan, "demokrasi" adalah salah satu dari 3 (tiga) bentuk pemerintahan menurut pembagian Herodotus dan Aristoteles. Bentuk lain menurut kedua ahli pikir tersebut adalah Monarchie" dan Oligarchie. Pembagian ini didasarkan pada jumlah orang yang memegang pemerintahan. Menurut mereka, jika pemerintahan dipegang oleh satu orang, maka disebut Monarchie, jika dipegang oleh sejumlah orang disebut Oligarchie, sedangkan jika pemerintahan berada di tangan rakyat secara bersama-sama, disebut Democretie. ${ }^{9}$

Pemerintahan demokrasi pada intinya ialah pemerintahan dari rakyat, oleh rakyat dan untuk rakyat. Dalam negara demokrasi, rakyat diikutsertakan dalam pengangkatan (pemilihan) penguasa. Di sini ada keinginan untuk mendekatkan hubungan antara penguasa dengan rakyat yang diperintah. ${ }^{10}$ Konsepsi demokrasilah yang memberikan landasan dan mekanisme kekuasaan berdasarkan prinsip persamaan dan kesederajatan manusia. Demokrasi menempatkan manusia sebagai pemilik kedaulatan yang kemudian

${ }^{9}$ Ibid., hal. 44-45.

${ }^{10}$ A. Mukti Arto, Konsepsi Ideal Mahkamah Agung, Pustaka Pelajar, Yogyakarta, 2001, hal. 15. dikenal dengan prinsip kedaulatan rakyat.

Sejatinya prinsip kedaulatan rakyat yang dikehendaki oleh demokrasi telah diadopsi dalam Pasal 1 ayat (2) UUD NRI Tahun 1945, yang menyebutkan bahwa: Kedaulatan berada di tangan rakyat dan dilaksanakan berdasarkan Undang-Undang Dasar. Untuk mengenali suatu negara apakah menerapkan prinsip demokrasi atau tidak, pada umumnya dapat dilihat dari beberapa kriteria, yakni:

a. Adanya hak berpendapat;

b. Hak dan derajat yang sama di hadapan hukum;

c. Hak berpartisipasi dalam proses pengambilan keputusan;

d. Hak mengikuti pemilihan umum;

e. Adanya pemilu serta pergantian kekuasaan secara teratur dan damai;

f. Adanya kontrol masyarakat;

g. Distribusi pendapatan secara adil dan lebih merata dalam masyarakat;

h. Kebebasan berusaha;

i. Hak memperoleh pendidikan;

j. Hak memperoleh informasi; dan

k. Adanya jaminan dan perlindungan terhadap hak-hak dasar dan bersifat universal setiap warga negara. ${ }^{11}$

Berdasarkan uraian tersebut di atas disimpulkan bahwa prinsip Negara demokrasi adalah sebagai berikut:

a. Pengambilan keputusan didasarkan pada kehendak rakyat; Untuk mewujudkan hal tersebut, maka harus ada lembaga yang akan menampung dan menyuarakan kehendak rakyat tersebut, seperti adanya lembaga

${ }^{11}$ Galang Asmara, Op., cit., hal. 49. 
perwakilan rakyat, adanya lembaga pemilihan umum.

b. Adanya kontrol rakyat atas segala tindakan yang dilakukan oleh penguasa di dalam menjalankan keputusan atau kebijaksanaan yang telah ditetapkan atas kehendak rakyat; Sebagai konsekuensinya, maka harus ada lembaga atau sarana yang mengontrol pemerintah oleh rakyat seperti diciptakan untuk Pers, lembaga Ombudsman dan lain-lain lembaga yang diberi fungsi pengawasan seperti lembaga perwakilan rakyat, pengadilan dan lain-lain.

c. Adanya jaminan bagi rakyat untuk menyatakan kehendak atau pendapatnya secara bebas; Hal ini adalah sebagai konsekuensi dari adanya keharusan pengambilan keputusan yang didasarkan atas kehendak rakyat, sehingga untuk menjamin obyektifitas atau kejujuran di dalam menyampaikan kehendaknya, maka rakyat harus mendapatkan jaminan kebebasan menyatakan kehendak. Berkaitan dengan hal tersebut, maka harus ada lembaga pemilihan umum yang bebas dan rahasia, kebebasan menyampaikan pikiran secara lisan maupun tulisan, melalui media masa dan lainlain. $^{12}$

Secara sepintas jika diperhatikan dari uraian tersebut di atas, maka konsekuensi dari sebuah negara demokrasi adalah apapun yang dilakukan oleh negara harus ada keterlibatan rakyat. Dan menjadi tanggung jawab negara demokrasi untuk memenuhi hak-hak rakyat tersebut untuk ikut berpartisipasi di dalamnya baik secara langsung

12 Ibid., hal. 50. maupun melalui keterwakilan. Hal ini juga merupakan bagian dari pada semangat munculnya ajaran trias politica dengan tujuan untuk membatasi kekuasaan pemerintah.

Di dalam UUD 1945 menempatkan DPD sebagai salah satu lembaga atau badan yang menyelenggarakan fungsi legislatif di samping adanya lembaga DPR. Mengingat dalam struktur ketatanegaraan Republik Indonesia menempatkan MPR sebagai badan perwakilan yang terdiri dari anggota DPR dan anggota DPD yang dipilih secara langsung melalui pemilihan umum. Oleh karena itu, kedudukan DPD sebenarnya sama halnya dengan DPR.

Lembaga perwakilan dinilai penting dalam sebuah negara baik negara demokrasi atau tidak, karena lembaga perwakilan atau biasa disebut parlemen lahir bukan karena ide demokrasi itu sendiri tetapi lahir di atas dampak dari sistem feodal. Keberadaan lembaga perwakilan daerah di tingkat pusat dinilai mempunyai peran yang sangat penting sebagaimana pentingnya pemerintahan daerah yang mandiri di Negara Kesatuan Republik Indonesia ini. Hal ini dikarenakan Indonesia tidak hanya memiliki rakyat yang berada di tingkat pusat tetapi juga di daerah. Potensi daerah hingga saat ini masih belum maksimal dimanfaatkan dan dikembangkan sehingga peranan perwakilan tentunya menjadi sosok yang akan mengisi kekosongan kursi kepentingan daerah itu sendiri.

Menarik untuk dikaji disini keberadaan lembaga perwakilan baru yaitu DPD. Idealnya, DPR dan DPD mampu bekerja bersama-sama dalam merumuskan sebuah 
rancangan undang-undang. Hanya saja karena cacatnya amandemen yang dilakukan terhadap UUD 1945, relasi yang muncul menjadi timpang. DPR memegang kekuasaan legislatif yang lebih besar, sedangkan DPD hanya sebagai badan yang memberi pertimbangan kepada DPR dalam hal persoalan-persoalan tertentu. Hal tersebut sebagai implikasi penerapan sistem bikameral di Indonesia secara tidak murni. ${ }^{13}$

Keberadaan dua kamar dalam parlemen pada awalnya hanya ada di negara dengan bentuk federal yang bertujuan untuk melindungi formulasi federasi itu sendiri. Namun, dalam perkembangannya sistem bikameral juga dipraktekkan dalam negara kesatuan. Dalam sistem parlementer misalkan, ada dua alasan utama penerapan dari sistem bikameral ini yaitu ${ }^{14}$ :

1. Adanya kebutuhan untuk menjamin keseimbangan yang lebih stabil antara pihak eksekutif dan pihak legislatif;

2. Keinginan untuk membuat sistem pemerintahan yang lebih efisien dan lancar melalui revising chamber untuk menjaga a careful on the sometimes hasty

${ }^{13}$ Lihat Bagir Manan, DPR, DPD dan MPR Dalam UUD 1945 Baru, UUI Press, Yogyakarta, 2005, hal. 27.

14 Lihat Inter Parliamentarty Union, Parliament: A Comparative Study on the Structure and Functioning of Representative Institution in Fourty One Countries, (New York: Praeger, 1963), hlm. 7-8 dalam Jimly, Format Kelembagaan... Op Cit., hlm. 164. Sebagimana dikutip oleh Ryan Muthiara Wasti, Fungsi Representasi Dewan Perwakilan Daerah Republik Imdonesia Sebagai Lembaga Perwakilan Daerah, Jurnal Hukum dan Pembangunan Tahun ke47 No.4 Oktober-Desember 2017, hal. 443. decision yang dikenal dengan double check.

DPD merupakan lembaga perwakilan yang dibentuk dengan tujuan untuk mengakomodasi kepentingan daerah yang tidak dapat diakomodir oleh DPR terutama setelah ditiadakannya utusan daerah dan utusan golongan dalam keanggotaan MPR. Perbedaan antara DPD dan DPR dimana DPD merupakan representasi lokal sedangkan DPR merupakan representasi orang melalui partai politik menjadi sebuah peluang yang positif untuk check and balances di dalam lembaga legislatif ini sendiri. Di satu sisi, keberadaan DPD dinilai sangat penting, namun disisi lain DPD belum diberikan kewenangan yang sama dengan DPR sehingga kedudukan diantara keduanya tidak seimbang.

Namun yang membedakan antara keduanya adalah terkait dengan kepentingan yang diwakili oleh masing-masing lembaga DPR dan DPD. Selain itu, yang paling menonjol adalah terkait dengan perbedaan kewenangan yang dimiliki oleh DPR maupun DPD. Karena bagaimana pun kedudukan suatu lembaga negara itu lebih cenderung ditentukan oleh kewenangan yang dimilikinya. Untuk melihat perbedaan kewenangan yang dimiliki oleh DPR dan DPD, maka berikut ini akan diuraikan mengenai kewenangan dari pada masingmasing kedua lembagaa tersebut.

Sebagaimana ditentukan dalam Pasal 20A UUD 1945, DPR mempunyai fungsi dan hak sebagai berikut: 
1. Dewan Perwakilan Rakyat memiliki fungsi legislasi, fungsi anggaran dan fungsi pengawasan.

2. Dalam melaksanakan fungsinya selain hak yang diatur dalam pasal-pasal lain Undang Undang Dasar ini, Dewan Perwakilan Rakyat mempnyai hak interpelasi, hak angket dan hak menyatakan pendapat.

3. Selain hak yang diatur dalam pasal-pasal lain Undang Undang Dasar ini, setiap anggota Dewan Perwakilan Rakyat mempunyai hak mengajukan pertanyaan, menyampaikan usul dan pendapat serta hak imunitas.

4. Ketentuan lebih lajut tentang Hak Dewan Perwakilan Rakyat dan hak anggota Dewan Perwakilan Rakyat diatur dalam Undang Undang.

Sedangkan dalam Pasal 22D

UUD 1945, ditentukan tentang tugas dan wewenang DPD antara lain:

1. Dewan Perwakilan Daerah dapat mengajukan kepada Dewan Perwakilan Rakyat, rancangan undang undang yang berkaitan dengan otonomi daerah, pembentukan dan pemekaran, serta penggabungan daerah, pengelolaan sumber daya alam dan sumber daya ekonomi lainnya, serta yang berkaitan dengan perimbangan keuangan pusat dan daerah.

2. Dewan Perwakilan Daerah ikut membahas Rancangan Undang Undang yang berkaitan dengan otonomi daerah, hubungan pusat dan daerah, pembentukan, pemekaran, dan penggabungan daerah, pengelolaan sumber daya alam dan sumber daya ekonomi lainnya serta perimbangan keuangan pusat dan daerah, serta memberikan pertimbangan kepada Dewan Perwakilan Rakyat atas ransangan Undang Undang anggaran pendapatan dan belanja Negara dan rancangan undang undang yang berkaitan dengan pajak, pendidikan dan agama.

3. Dewan Perwakilan Daerah dapat melakukan pengawasan atas pelaksanaan undang undang mengenai otonomi daerah, pembentukan pemekaran, dan penggabungan daerah, hubungan pusat dan daerah, pengelolaan sumber daya alam dan sumber daya ekonomi lainnya, pelaksanaan anggaran pendapatan dan belanja Negara, pajak, pendidikan, dan agama serta menyampaikan hasil pengawasannya itu kepada Dewan Perwakilan Rakyat sebagai bahan pertimbangan untuk ditindaklanjuti.

Jumlah anggota DPR ditentukan oleh pembagi pemilih yang akan diatur dengan undang-undang. Masa jabatan anggota DPR selama 5 (lima) tahun. Dewan Perwakilan Daerah (DPD) adalah sebuah lembaga perwakilan seperti halnya DPR yang kita kenal selama ini. Bedanya, jika DPR mewakili masyarakat dengan jumlah penduduk tertentu, maka DPD mewakili masyarakat pada wilayah tertentu. Keberadaan DPD ini bertujuan untuk menjadi jembatan bagi aspirasi masyarakat daerah dalam pembuatan kebijakan pada tingkat nasional.

Diakomodasinya DPD dalam sistem perwakilan Indonesia menurut pendapat Bagir Manan 
memiliki 2 (dua) alasan, antara lain ${ }^{15}$ :

Pertama, adanya gagasan untuk merubah sistem perwakilan menjadi legislatif bikameral, DPD dan DPR digambarkan serupa dengan sistem perwakilan Amerika Serikat yang terdiri atas senat sebagai perwakilan negara bagian (DPD) dan house of representatif sebagai perwakilan rakyat secara keseluruhan (DPR). Kedua, adanya gagasan untuk meningkatkan keikutsertaan daerah terhadap jalannya politik dan pengelolaan negara.

Oleh karena itu, bahwa semangat munculnya gagasan parlemen dua kamar adalah dalam rangka mengakomodir kepentingankepentingan di daerah. Adapun ketidakefektifan DPD sebagai lembaga perwakilan dalam menjalankan tugasnya ditenggarai terjadi karena beberapa faktor. Pertama, miskonsepsi dalam menerapkan konsep bikameral. Kedua, kewenangan DPD yang sangat terbatas dan hanya terkait dengan soal-soal kedaerahan. Ketiga, DPD dibentuk untuk mencegah timbulnya kembali hegemoni lembaga eksekutif, namun kemudian perimbangan kekuasaan tidak berjalan dengan efektif karena besarnya kewenangan yang dimiliki oleh DPR.

Pada prinsipnya sistem perwakilan rakyat dapat dibagi menjadi 2 (dua) yaitu keterwakilan dalam gagasan dan keterwakilan dalam kehadiran. Keterwakilan

${ }^{15}$ Lihat Bagir Manan, dalam Megawati \& Ali Murtopo, Parlemen Bikameral Dalam Sistem Ketatanegaraan Indonesia: Sebuah Evaluasi, Fakultas Hukum UAI Press, Yogyakarta, 2004, hal. 108. penduduk dalam DPR pada dasarnya adalah keterwakilan dalam gagasan karena pemilihan terhadap calon legislatif atau partai sematamata berdasarkan atas program, preferensi dan aspirasi politik yang mereka ajukan dan disetujui rakyat yang memilihnya. Kelemahan keterwakilan tersebut adalah dimana anggota DPR akan mengklaim dirinya sebagai wakil dari rakyat, sehingga muncul tuntutan bahwa keterwakilan gagasan harus dilengkapi dengan keterwakilan dalam kehadiran rakyat melalui calon yang dipilihnya sendiri, hadir mewakili dirinya sendiri dalam lembaga perwakilan yang terwujud dalam DPR. ${ }^{16}$ Dalam sistem bikameral murni, kedua lembaga perwakilan yang ada mempunyai fungsi yang setara dan setingkat di bidang legislasi, anggaran dan pengawasan.

Dalam sistem bikameral sebagian atau seluruh rancangan undang-undang memerlukan pembahasan dan persetujuan kedua lembaga perwakilan. Sistem bikameral sendiri bervariasi penerapannya tetapi memiliki prinsip-prinsip yang relatif sama. DPR bekerja untuk konstituen secara nasional, sedangkan DPD untuk daerah. Dalam sistem bikameral murni, DPD dapat memveto atau menolak setiap Undang-Undang yang dihasilkan oleh DPR. Di Indonesia, sistem bikameral terakomodasi dalam amandemen ketiga dan keempat dimana susunan dan kedudukan DPR dan DPD tidak setara seperti sistem bikameral murni, karena

\footnotetext{
${ }^{16}$ Jimly Asshiddiqie, Pokok-Pokok Hukum Tata Negara Indonesia Pasca Reformasi, Bhuana Ilmu Populer, Jakarta, 2007, hal. 153.
} 
DPD tidak memiliki kekuasaan penuh dalam bidang legislasi. Hal tersebut sebagaimana disebutkan dalam Pasal 20 ayat (2) UUD 1945 bahwa setiap RUU dibahas bersama DPR dan Presiden. ${ }^{17}$

Bagaimanakah dengan peran dua lembaga perwakilan DPD dan DPR tersebut dalam parlemen Indonesia, khususnya dalam pelaksanaan fungsi legislasi atau pembentukan undang-undang? Jika ada dua kamar, maka tentu rumahnya tetap satu. Untuk itu, MPR tetap dipertahankan keberadaannya sebagai nama dari rumah antara DPR dan DPD. DPR dan DPD sama-sama mewakili rakyat dengan spektrum yang berbeda. DPD mewakili rakyat dalam konteks kedaerahan dan berorientasi kepada kepentingan daerah. Sedangkan DPR mewakili rakyat pada umumnya dengan orientasi kepentingan nasional, yang prosedur dan mekanisme pemilihannya berbeda satu dengan yang lain.

Sistem bikameral lebih banyak dianut oleh negara-negara yang berbentuk federasi seperti Amerika serikat. Dengan sistem ini negara bagian dalam federasi terwakili dalam parlemen melalui senat. Dalam praktek ketatanegaraan sistem legislasi bikameral ini menurut Dahlan Thaib mempunyai beberapa kelebihan, antara lain:

1. Secara resmi dapat mewakili seluruh atau beragam pemilih,

17 Priyatmoko, "Hubungan Kerja dan Mekanisme Kerja DPD dengan DPR dan Lembaga Negara Lainnya". Makalah disampaikan pada Focus Group Discussion kerjasama dengan Setjen MPR RI dengan UNDP-UNIBRAW di Unibraw Malang, 26 Maret 2003. misalnya negara bagian, wilayah, etnik atau golongan.

2. Memfasilitasi pendekatan musyawarah dalam penyusunan peraturan perundangan.

3. Mencegah disahkannya Undang Undang yang cacat atau ceroboh.

4. Mekanisme pengawasan lebih baik atas lembaga eksekutif. ${ }^{18}$

Pada dasarnya lembaga perwakilan mempunyai tiga fungsi utama, antara lain, fungsi perundang-undangan, fungsi pengawasan, dan sarana pendidikan politik:

1. Fungsi perundangan, yaitu membentuk Undang Undang, serta meratifikasi perjanjianperjanjian dengan luar negeri dan lain sebagainya.

2. Fungsi pengawasan, yaitu fungsi yang dilakukan oleh lembaga perwakilan untuk mengawasi eksekutif (pemerintah). Hal ini dimaksudkan agar berfungsi sesuai dengan undang-undang yang dibentuk oleh lembaga perwakilan, dan untuk melaksanakan fungsi ini lembaga perwakilan diberi hak-hak yaitu: Hak interpelasi (Hak Meminta keterangan); Hak Angket (Hak mengadakan penyelidikan); Hak Bertanya; Hak Amandemen (Hak mengadakan perubahan); dan Hak mengajukan Rancangan Undang Undang.

3. Sarana pendidikan politik, yaitu rakyat di didik untuk mengetahui persoalan yang menyangkut kepentingan umum, melalui pembahasan-pembahasan, pembicaraan-pembicaraan serta kebijakan-kebijakan yang

\footnotetext{
18 Jimly Assiddiqie, Format Kelembagaan Negara Dan Pergeseran Kekuasaan Dalam UUD 1945, Fakultas Hukum UII Press, Yogyakarta, 2004, hal. 211.
} 
dilakukan oleh lembaga perwakilan rakyat yang dimuat dalam media masa agar rakyat mengetahui dengan sadar akan hak dan kewajibannya sebagai warga negara. ${ }^{19}$

Dalam parlemen di Indonesia fungsi-fungsi tersebut hanya diberikan kepada DPR saja, tidak kepada DPD. Selanjutnya tugas keparlemenan yang selama ini dijalankan oleh MPR untuk seterusnya berdasarkan UUD 1945 akan dijalankan oleh DPR dan DPD kecuali atas tiga hal, yakni mengubah dan menetapkan Undang-Undang Dasar, melantik Presiden dan atau Wakil Presiden, serta meminta pertanggungjawaban Presiden dan atau Wakil Presiden dalam masa jabatannya.

Di dalam kaitannya dengan fungsi lembaga perwakilan, DPD mempunyai kewenangan legislasi, anggaran, maupun pengawasan yang hanya terbatas pada rancangan undang-undang yang berkaitan dengan otonomi daerah, hubungan pusat dan daerah, pembentukan dan pemekaran serta penggabungan daerah, pengelolaan sumber daya alam dan sumber daya ekonomi lainnya serta yang berkaitan dengan perimbangan keuangan pusat dan daerah.

Ada banyak alasan untuk diadakannya kamar kedua dalam struktur parlemen di negara di dunia khususnya di Indonesia yaitu sebagaimana disampaikan oleh CF. Strong bahwa keberadaan kamar kedua di negara-negara dengan lembaga legislatif lebih dari satu adalah dalam rangka memberikan tempat keterwakilan bagi pihak atau

19 Saldi Isra, Pergeseran Fungsi Legislasi, Raja Grafindo Persada, Jakarta, 2010, hal. 210. kelompok yang belum terwakili dalam kamar pertama. ${ }^{20}$ Dalam konsep sistem perwakilan, baik dalam sistem perwakilan satu kamar (unikameral), dua kamar (bikameral), maupun banyak kamar (multikameral), terdapat prasyarat bahwa kamar di dalam lembaga perwakilan yang dimaksud mempunyai kewenangan yang jelas (original power). Perbedaan di antara kamar kamar yang ada di dalam lembaga perwakilan tersebut hanyalah pada besaran kewenangan yang dimiliki, yang pada umumnya lebih banyak pada kamar yang lebih rendah (the lower house). ${ }^{21}$

I Dewa Gede Palguna menyatakan bahwa berdasarkan ketentuan dalam Pasal 22 D, maka dapat dikatakan bahwa Dewan Perwakilan Daerah mempunyai fungsi-fungsi yaitu:

1. Fungsi legislasi atau perumusan undang-undang. Fungsi ini seperti tercantum dalam Pasal $22 \mathrm{D}$ ayat (1) dan (2) Undang- Undang Dasar 1945.

2. Fungsi konsultasi atau fungsi pertimbangan. Fungsi ini seperti tercantum dalam Pasal $22 \mathrm{D}$ ayat (2) Undang-Undang Dasar 1945, dan termasuk pula dalam memberikan pertimbangan kepada Dewan Perwakilan Rakyat dalam pemilihan anggota Badan Pemeriksa Keuangan.

20 Lihat C.F. Strong, Modern Political Constitution; An Introduction to the Comparative Study of Their History ang Existing Forms, (London: Sidwick \& Jackson, 1963), hlm.195-196. Sebagaimana dikutip oleh Ryan Muthiara Wasti, Op.cit., hal. 448.

21 Firman Manan, Dewan Perwakilan Daerah Republik Indonesia Dalam Sistem Pemerintahan Republik Indonesia, Jurnal Ilmu Pemerintahan CosmoGov, Vol.1 No.1, April 2015, hal. 54. 
3. Fungsi kontrol. Fungsi ini seperti tercantum dalam Pasal 22 D ayat (3) Undang-Undang Dasar 1945.

4. Fungsi anggaran. Fungsi ini terlihat dari diberikannya wewenang kepada Dewan Perwakilan Daerah untuk mengajukan rancangan undangundang tentang perimbangan keuangan pusat dan daerah, wewenang untuk memberikan pertimbangan terhadap rancangan undang-undang anggaran pendapatan dan belanja negara, serta wewenang untuk dapat ikut melakukan pengawasan terhadap pelaksanaan anggaran pendapatan dan belanja negara tersebut. ${ }^{22}$

Selanjutnya dalam Pasal 248 ayat (1) Undang-Undang Nomor 17 Tahun 2014 Tentang Majelis Permusyawaratan Rakyat, Dewan Perwakilan Rakyat, Dewan Perwakilan Daerah, Dan Dewan Perwakilan Rakyat Daerah (UU MD3) menentukan bahwa DPD mempunyai fungsi sebagai berikut:

1. Pengajuan rancangan undangundang yang berkaitan dengan otonomi daerah, hubungan pusat dan daerah, pembentukan dan pemekaran serta penggabungan daerah, pengelolaan sumber daya alam dan sumber daya ekonomi lainnya, serta yang berkaitan

${ }^{22}$ Lihat I Dewa Palguna, dalam kumpulan tulisan buku: Dewan Perwakilan Daerah dalam Sistem Ketatanegaraan Republik Indonesia, Susunan dan Kedudukan Dewan Perwakilan Daerah, Sekretariat Negara, Jakarta, 2004, hal. 64-65. Sebagimana dikutip oleh Ahmad Rosidi, Kewenangan Dewan Perwakilan Daerah Dalam Sistem Ketatanegaraan Republik Indonesia Berdasarkan Undang-Undang Dasar Negara Republik Indonesia Tahun 194, Jurnal IUS Vol. III, No. 8 Agustus 2015, hal. 249. dengan perimbangan keuangan pusat dan daerah kepada DPR;

2. Ikut dalam pembahasan rancangan undang-undang yang berkaitan dengan otonomi daerah, hubungan pusat dan daerah, pembentukan, pemekaran dan penggabungan daerah, pengelolaan sumber daya alam dan sumber daya ekonomi lainnya, serta perimbangan keuangan pusat dan daerah;

3. Pemberian pertimbangan kepada DPR atas rancangan undangundang tentang anggaran pendapatan dan belanja negara dan rancangan undang-undang yang berkaitan dengan pajak, pendidikan, dan agama; serta

4. Pengawasan atas pelaksanaan undang-undang mengenai otonomi daerah, pembentukan, pemekaran dan penggabungan daerah, hubungan pusat dan daerah, pengelolaan sumber daya alam dan sumber daya ekonomi lainnya, pelaksanaan APBN, pajak, pendidikan, dan agama.

Sedangkan wewenang dan tugas DPD sebagaimana diatur dalam Pasal 249 UU MD3 adalah sebagai berikut:

1. mengajukan rancangan undangundang yang berkaitan dengan otonomi daerah, hubungan pusat dan daerah, pembentukan dan pemekaran serta penggabungan daerah, pengelolaan sumber daya alam dan sumber daya ekonomi lainnya, serta yang berkaitan dengan perimbangan keuangan pusat dan daerah kepada DPR;

2. Ikut membahas rancangan undang-undang yang berkaitan dengan hal sebagaimana dimaksud dalam huruf a;

3. Menyusun dan menyampaikan daftar inventaris masalah rancangan undang-undang yang berasal dari DPR atau Presiden 
yang berkaitan dengan hal sebagaimana dimaksud dalam huruf a;

4. Memberikan pertimbangan kepada DPR atas rancangan undang-undang tentang APBN dan rancangan undang-undang yang berkaitan dengan pajak, pendidikan, dan agama;

5. Dapat melakukan pengawasan atas pelaksanaan undang-undang mengenai otonomi daerah, pembentukan, pemekaran, dan penggabungan daerah, hubungan pusat dan daerah, pengelolaan sumber daya alam, dan sumber daya ekonomi lainnya, pelaksanaan APBN, pajak, pendidikan, dan agama;

6. Menyampaikan hasil pengawasan atas pelaksanaan undang-undang mengenai otonomi daerah, pembentukan, pemekaran, dan penggabungan daerah, hubungan pusat dan daerah, pengelolaan sumber daya alam dan sumber daya ekonomi lainnya, pelaksanaan undang-undang APBN, pajak, pendidikan, dan agama kepada DPR sebagai bahan pertimbangan ditindaklanjuti;

7. Menerima hasil pemeriksaan atas keuangan negara dari BPK sebagai bahan membuat pertimbangan kepada DPR tentang rancangan undang-undang yang berkaitan dengan APBN;

8. Memberikan pertimbangan kepada DPR dalam pemilihan anggota BPK; dan

\section{REFERENSI}

Ahmad Rosidi, Kewenangan Dewan Perwakilan Daerah Dalam Sistem Ketatanegaraan Republik Indonesia Berdasarkan Undang-
9. Menyusun program legislasi nasional yang berkaitan dengan otonomi daerah, hubungan pusat dan daerah, pembentukan dan pemekaran serta penggabungan daerah, pengelolaan sumber daya alam dan sumber daya ekonomi lainnya, serta yang berkaitan dengan perimbangan keuangan pusat dan daerah.

Maka dari uraian tersebut di atas dapat terlihat bagaimana peran dan fungsi DPD sebagai lembaga parlemen jika dibandingkan dengan peran dan fungsi DPR sangat jauh sekali perbedaannya.

\section{PENUTUP}

Peran dan fungsi DPD dalam sistem parlemen bikameral Indonesia, secara konstitusional hanya terbatas pada fungsi legislasi, fungsi anggaran, maupun fungsi kontrol yang berkaitan dengan materi atau substansi mengenai otonomi daerah, hubungan pusat dan daerah, pembentukan dan pemekaran serta penggabungan daerah, pengelolaan sumber daya alam dan sumber daya ekonomi lainnya serta yang berkaitan dengan perimbangan keuangan pusat dan daerah.

Perlu dilakukan penguatan peran dan fungsi DPD dengan memberikan kewenangan yang lebih guna mewujudkan demokrasi yang stabil dan berkualitas terutama mengenai fungsi pokok DPD sebagai badan perwakilan seperti halnya dengan DPR.

\section{Undang Dasar Negara Republik Indonesia Tahun 194, Jurnal IUS Vol. III, No. 8 Agustus 2015.}


Jurnal Independent

A. Mukti Arto, Konsepsi Ideal Mahkamah Agung, Pustaka Pelajar, Yogyakarta, 2001.

Bagir Manan, DPR, DPD dan MPR Dalam UUD 1945 Baru, UUI Press, Yogyakarta, 2005.

Eggy Sudjana, Dasar dan Struktur Ketatanegaraan Indonesia (edisi revisi), Jakarta, Rinneka Cipta, 2008.

Firman Manan, Dewan Perwakilan Daerah Republik Indonesia Dalam Sistem Pemerintahan Republik Indonesia, Jurnal Ilmu Pemerintahan CosmoGov, Vol.1 No.1, April 2015.

Galang Asmara, Ombudsman Republik Indonesia Dalam Sistem Ketatanegaraan Republik Indonesia, Laksbang Yustitia, Surabaya, 2012.

Jimly Assiddiqie, Format Kelembagaan Negara Dan Pergeseran Kekuasaan Dalam UUD 1945, Fakultas Hukum UII Press, Yogyakarta, 2004.

-------, Pokok-Pokok Hukum Tata Negara Indonesia Pasca Reformasi, Bhuana Ilmu Populer, Jakarta, 2007.

-------, Hukum Tata Negara dan Pilar-Pilar Demokrasi, Sinar Grafika, Jakarta, 2011.

Megawati \& Ali Murtopo, Parlemen Bikameral Dalam Sistem Ketatanegaraan Indonesia: Sebuah Evaluasi, Fakultas Hukum UAI Press, Yogyakarta, 2004.
Peter Mahmud Marzuki. (2009). Penelitian Hukum, Cet. 5, Edisi Pertama, Jakarta: PT Interpratama Offset.

-----, (2010). Penelitian Hukum, Jakarta: Kencana Prenada Media Group.

Priyatmoko, "Hubungan Kerja dan Mekanisme Kerja DPD dengan DPR dan Lembaga Negara Lainnya". Makalah disampaikan pada Focus Group Discussion kerjasama dengan Setjen MPR RI dengan UNDP-UNIBRAW di Unibraw Malang, 26 Maret 2003.

Ryan Muthiara Wasti, Fungsi Representasi Dewan Perwakilan Daerah Republik Imdonesia Sebagai Lembaga Perwakilan Daerah, Jurnal Hukum dan Pembangunan Tahun ke-47 No.4 OktoberDesember 2017.

Saldi Isra, Pergeseran Fungsi Legislasi, Raja Grafindo Persada, Jakarta, 2010.

Undang-Undang Dasar Negara Republik Indonesia Tahun 1945.

Undang-Undang Republik Indonesia Nomor 2 Tahun 2018 Tentang Perubahan Kedua Atas Undang-Undang Nomor 17 Tahun 2014 Tentang Majelis Permusyawaratan Rakyat, Dewan Perwakilan Rakyat, Dewan Perwakilan Daerah, Dan Dewan Perwakilan Rakyat Daerah sebagaimana telah diubah dengan Undang-Undang 
Jurnal Independent

Nomor 13 Tahun 2019

Dewan Perwakilan Daerah,

Tentang Majelis

Dan Dewan Perwakilan

Permusyawaratan Rakyat,

Dewan Perwakilan Rakyat,

Rakyat Daerah. 